\title{
How long can austerity persist? The factors that sustain fiscal consolidations
}

\author{
David Lodge, European Central Bank
}

Marta Rodríguez-Vives, European Central Bank

\begin{abstract}
To put public debt on a sustainable path, many governments face the task of enacting large fiscal consolidation followed by years of sustained primary surpluses. By estimating hazard functions for the duration of consolidations, we analyse the features of past consolidation efforts across a panel of advanced economies. Our contribution is to identify the factors that help to start and sustain consolidations, separately discussing governments' "commitment" to the cause as well as their "capacity" for action. Our analysis suggests that longer consolidations are initiated when public debt is high, fiscal deficits are large, the interest burden heavy and long-term sovereign bond yields elevated. However, we also find that a countries' "capacity" to change course is important. Higher initial private sector savings, a stronger external balance, a competitive position and stable financial conditions appear to provide more scope for governments to sustain longer-lasting consolidations. Once we have controlled for the initial macroeconomic conditions, there is a lesser role for governments' commitment as reflected in factors such as the composition and the pace of the fiscal adjustment or the political cycle in explaining the duration of consolidation. However, commitment to permanent, rather than temporary, fiscal adjustment is key.
\end{abstract}

\section{JEL Classification}

C23; E20; E62; H62

\section{Keywords}

Government debt; government deficit; fiscal consolidation; panel data; survival function

\section{Acknowledgements}

The opinions expressed herein are those of the authors, and do not necessarily reflect the views of the ECB or the Eurosystem. We thank Phillip Rother, Ad van Riet, the Editor and two anonymous referees for their useful comments and suggestions. 


\section{Introduction}

One legacy of the recent financial and economic crisis has been a substantial fiscal burden for most developed countries. Heavy financial sector support, deep economic contraction, and counter-cyclical fiscal policies have all sharply raised government debt-to-GDP ratios since 2008 . The legacy effects are potentially severe: increased government borrowing is likely to raise governments' financing costs, impact on private financing conditions, crowd-out private investment and lower potential economic growth (Hartwig Lojsch, Rodríguez-Vives and Slavik, 2011). Restoring fiscal sustainability is thus a top policy priority across much of the developed world. To ensure that government debt is on a sustainable path many governments inside and outside the euro area must enact large fiscal consolidation and then sustain substantial primary budget surpluses for many years. That is especially true for the euro area countries currently under EU/IMF programmes, where countries commit to rein in deficits and reform their economies.

The challenge is big but not unknown. Several analyses, from the ECB and other international institutions, have highlighted the past experience of countries that managed to sustain fiscal consolidations and/or large primary budget surpluses over some years $(E C B, 2011)$. However, to understand properly the relevance of fiscal adjustment processes of the past, we need to analyse how different factors supporting the length of periods of government action to improve their fiscal balances. In this vein, there is a rich stream of empirical papers that have tried to understand the possible factors supporting "successful" fiscal consolidations. The academic literature systematically refers to the expression "success" and provides a number of definitions to it. However, the term "successful" is controversial. The aims and effects of a period of consolidation would be perceived differently by different actors which may have conflicting preferences about choices for achieving fiscal sustainability. ${ }^{1}$ While one stream of the literature defines "success" as the ability to significantly reduce government debt over the consolidation period (e.g. Heylen and Everaert, 2000), our work, in line with another stream of existing studies, measures the persistence (length or longevity) of the fiscal consolidation effort over time.

In this article, we draw from the literature that analyses the factors affecting the length of consolidations, using duration analysis to estimating hazard functions (e.g. von Hagen, Hughes, and Strauch (2002); Gupta, Clements, Baldacci and Mulas-Granados (2004); Maroto Illera and Mulas-Granados (2008); Agnello, Castro and Sousa (2012)). The bulk of previous empirical research on the determinants affecting consolidation makes use of case studies, descriptive statistics and econometric techniques - mainly regressions with "successful" fiscal consolidations as dummy variable (e.g. Alesina and Ardagna (1998); Guichard, Kennedy, Wurzel and Andre (2007)). ${ }^{2}$ The results of existing research differ, not only because of methodological differences, but also due to the different definitions of "success". The benefit of duration analysis for our purpose is that, as Gupta et al. (2004) argue, it enables us to treat the duration of fiscal consolidation as endogenous. In contrast to empirical studies which use a descriptive approach to assess the determinants of past adjustment episodes, duration analysis makes use

\footnotetext{
${ }^{1}$ Moreover, another interesting angle to explore would be whether policy makers with their choices in the fiscal consolidation mix are successful in limiting the pressure exerted by organized interest groups towards increasing quasi-private expenditure, such as the recipients of current and capital grants (e.g. Buchanan and Tullock (1962)), or in reducing the perception of fiscal illusion (Buchanan and Wagner (1977)).

2 Other approaches to overcome shortcomings of regression analysis, include the use of model averaging techniques by Hernández de Cos and Moral-Benito (2011) which implies considering and estimating all the possible regressions and subsequently construct a weighted average as the estimate of the variables (determinant of consolidations).
} 
of all the information available in the data. ${ }^{3}$ The distinction is important: to understand what helps sustain a long-lasting consolidation effort, we also need to analyse the failures, those that stopped after only a short period of time. In doing so, we aim at addressing one of the major challenges facing several euro area countries: how likely is it that a government will be able to enact large fiscal consolidations over a number of years? And what factors are likely to support their efforts? No doubt it has been a key question posed by capital markets as sovereign bond spreads have widened since the onset of financial crisis in 2007. But this is just one approach to analysing past experiences with fiscal consolidation and it has quite a narrow focus: it asks how long governments have managed to sustain uninterrupted periods of consolidation in the past and what factors affected their ability to do so? It does not directly comment either on debt sustainability, the success of fiscal consolidation in achieving a lasting reduction in government debt ratios nor does it deal with the consequences of consolidation - either for growth or welfare.

\section{Candidate factors sustaining the length of fiscal consolidations}

Our contribution is to provide a systematic and comprehensive analysis of candidate determinants of duration of fiscal consolidation applied to 20 advanced economies between 1970 and 2010. We group the potential main factors - mostly justified by the literature as likely to sustaining consolidations - into three types of variables (see overview Table 1). First, we refer to the "push factors", which act as circumstances where adjustment is likely to start. Lengthy consolidations are frequently 'forced' upon governments when fiscal deficits and government debt are large, but also when the interest burden is heavy and long-term sovereign bond yields are elevated. Second, once consolidation has started we identify the "pull" factors that sustain the adjustment over time. We separate these variables into two sets: governments' "capacity" for action, or in other words, a wide range of macroeconomic conditions that might enable and facilitate lengthy fiscal consolidation; and governments' "commitment", or the fiscal policy and political factors that might support governments' willingness to pursue painful consolidations. Other papers have already analysed, mostly using regressions but also duration analyses, ${ }^{4}$ simultaneously several factors sustaining consolidation in a comprehensive way. However, as explained in the remainder of this section, the emphasis has been largely on the fiscal policy and political factors that affect consolidations. Papers that also consider the macroeconomic conditions are typically limited to analysing the evolution of the growth rate of GDP or output gap. Some studies have extended the analysis of economic conditions to other variables - competitiveness, the international economic environment, or monetary conditions - but there has been a clear gap in empirical research on the role of financial or private sector balance sheets in sustaining fiscal consolidations.

\footnotetext{
3 The survival analysis comes originally from medical research, but it started to be applied in socioeconomic research in the 1970s and 1980s to plausibly model the behaviour of complex issues- also denominated duration analysis. For instance, in labour economics, empirical questions about employment can be specified in the language of hazard functions such as the longer a job is held, the less likely it is to be lost (Kiefer, 1988) or, in housing markets to analyse the duration of house price upturns and downturns (Bracke, 2011).

${ }^{4}$ Although duration analysis techniques have already been applied to study the persistence of fiscal consolidations, some related studies apply different sample period and countries (e.g. EU-15 countries during 1960-2004 by Maroto Illera and Mulas-Granados (2008); or 25 emerging countries during 19802001 by Gupta et. al (2004)).
} 
Table 1: Candidate determinants explaining the length of fiscal consolidation episodes

\begin{tabular}{|c|c|c|c|}
\hline & & Variables & Indicators \\
\hline \multirow{3}{*}{ 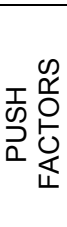 } & \multirow{3}{*}{ 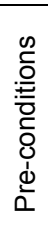 } & Budget balance position & Initial primary budget balance \\
\hline & & Government indebtedness & $\begin{array}{c}\text { Initial stock government debt-to-GDP } \\
\text { ratio }\end{array}$ \\
\hline & & Cost of financing & $\begin{array}{l}\text { Government interest payments } \\
\text { Short-term interest rate } \\
\text { Long-term bond yields }\end{array}$ \\
\hline \multirow{12}{*}{ 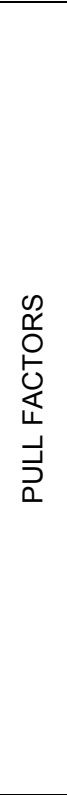 } & \multirow{7}{*}{ 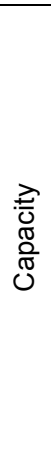 } & Growth & GDP \\
\hline & & Monetary conditions & $\begin{array}{l}\text { Inflation rate } \\
\text { Interest rate }\end{array}$ \\
\hline & & External positions & Current account balance \\
\hline & & International economic conditions & World GDP \\
\hline & & Competitiveness & $\begin{array}{c}\text { Real exchange rate } \\
\text { Unit labour cost }\end{array}$ \\
\hline & & Private sector balance sheets & $\begin{array}{c}\text { Stock of private debt } \\
\text { Private sector saving } \\
\text { Private sector net lending }\end{array}$ \\
\hline & & $\begin{array}{l}\text { Financial conditions and financial } \\
\text { imbalances }\end{array}$ & $\begin{array}{l}\text { Asset price developments } \\
\text { Credit growth } \\
\text { Financial crisis dummy variable }\end{array}$ \\
\hline & \multirow{5}{*}{ 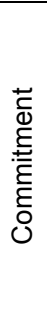 } & Composition of consolidation & $\begin{array}{l}\text { Consolidation on the revenue side versus } \\
\text { consolidation on the expenditure side }\end{array}$ \\
\hline & & Pace of adjustment & $\begin{array}{l}\text { Size of the adjustment effort } \\
\text { Degree of frontloading }\end{array}$ \\
\hline & & Fiscal rules & $\begin{array}{c}\text { Expenditure rules } \\
\text { Budget balance rules } \\
\text { Strength of the fiscal rules }\end{array}$ \\
\hline & & Durability of the adjustment & $\begin{array}{c}\text { Structural consolidation versus } \\
\text { temporary and one-offs }\end{array}$ \\
\hline & & Political factors & Elections, as dummy variable \\
\hline
\end{tabular}

Source: Authors' classification based on European Commission (2007), and the references quoted therein.

Although there is no consensus or theoretical model of reference ${ }^{5}$ on the determinants driving "successful" consolidations a central focus of the literature has been the fiscal factors. Most papers note the role of initial fiscal conditions, in particular the influence of high initial debt or large fiscal deficits (e.g. European Commission (2007); Devries, Guajardo, Leigh and Pescatori (2011)). Also Guichard et al. (2007) conclude that fiscal consolidations tend to occur when large budget deficits threaten sustainability. This is reflected in the "pre-conditions" in Table 1. Under "commitment" we include the composition of the fiscal consolidation as its role has been strongly highlighted by the literature on past consolidations. In particular, there is a general preference for the expenditure-based adjustment over tax hikes. Von Hagen and Strauch (2001), for example, conclude that the 'good quality' of fiscal adjustments - i.e. the emphasis on expenditure reduction rather than tax increases - has an important effect on the persistence of consolidations. The literature appears to emphasise the effectiveness of reducing politically sensitive items such as government consumption (mainly government wages and employment), subsidies and social transfers (e.g. Alesina and Perotti (1995, 1997)). Heylen and Everaert (2000) confirmed these results with multivariate analysis, suggesting that, surprisingly, raising taxes on business proves also to be effective $^{6}$. Another pull factor of fiscal consolidation typically covered by the

\footnotetext{
${ }^{5}$ As pointed by Hernández de Cos and Moral-Benito (2011), the empirical research in this field is mostly based on selecting a single regression and dependant on the decision of which factors are relevant (based on its associated t-ratio).

${ }^{6}$ However, Molnár (2012) after examining 20 different revenue and expenditure items finds that the composition of the consolidation does not seem to explain its length.
} 
existing literature is the size and the speed of the fiscal adjustment. The general idea is that large and persistent fiscal adjustments contribute to success ${ }^{7}$ (e.g. Briotti (2004); Giavazzi and Pagano (1996)), which is linked to the credibility of governments in their consolidation strategies and expectations of future tax reductions. In relation to the speed, there is a preference for gradual consolidations, but more intense efforts (e.g. "cold showers") seem to be more effective than longer consolidations at high and rising debt levels and in low growth scenarios (European Commission (2007), Barrios et al., 2010). Moreover, we also consider under the "commitment", the possible role of fiscal governance factors as a framework for sustaining consolidation, as suggested by the literature ${ }^{8}$ (e.g. Briotti (2004), and Guichard, Kennedy, Wurzel and Andre (2007)). Although not explicitly contemplated by the relevant literature, we also test the durability of the adjustment undertaken by governments: whether it is based on structural consolidation over temporary and one-off measures. ${ }^{9}$ Finally, we also include under "commitment" the potential explanatory effect of political factors, via elections, in line with the growing literature - although the evidence is not conclusive (e.g. Alesina and Perotti (1995), Alesina et al. (1998), Larch and Turrini (2008)).

Another stream of the literature relates to the importance of the prevailing macroeconomic factors. Where papers assess the role of initial macroeconomic conditions the broad conclusions are that governments are 'pushed' into fiscal consolidations, in particular referring to weak public finances, but also when the initial macroeconomic indicators suggest a crisis situation (Ahrend, Catte and Price, 2006). Moreover, von Hagen et al. $(2001,2002){ }^{10}$, and Guichard et al. (2007) found that weak domestic economic pre-conditions also play a role in explaining the likelihood of starting "successful" fiscal consolidations. Once consolidation has started, there is also a need to analyse the wider macroeconomic factors that 'allow', or make room for adjustment. The leading indicator that seems to justify the role of the macroeconomic environment is output growth, and to a lesser extent monetary conditions, competitiveness and the international economic environment. In general, existing empirical findings tend to suggest that favourable economic growth (in terms of GDP or output gap) contributes to the success of consolidation strategies (e.g. Alesina and Perotti (1995), Ardagna (2004), Hernández de Cos and Moral-Benito (2011), Agnello et al. (2012)). The findings on monetary conditions are mixed: while the monetary stance could positively contribute by accommodating consolidation (e.g. Ardagna (2004)), other authors found no evidence (e.g. von Hagen and Strauch (2001)). The role of competitiveness through exchange rate policy is not conclusive either, but evidence tends to suggest a positive effect of exchange rate depreciation on the success of consolidations (e.g. Molnár, 2012). Alesina and Perotti (1997) found that floating exchange rates better support successful consolidations than fixed

\footnotetext{
${ }^{7}$ However, the results are not consistent across existing studies, also due to the different definitions of success. For instance, Heylen and Evaraert (2000) find only a weak evidence to support the view of the importance of the size of fiscal adjustment.

${ }^{8}$ However, some studies do not find a significant impact of the expenditure rules (European Commission, 2007) or on the budget deficit rules (Barrios et al. 2010) on their sustaining role in successful fiscal consolidations.

9 One-offs are temporary or non-recurrent fiscal operations that may substantially impact the government cyclically adjusted primary balance positively or negatively, e.g. capital revenues as result of pension transfers from the private sector to the social security system; sales of mobile phone licences; debt assumptions and debt cancellations; or tax amnesties (Joumard et al. 2008).

${ }^{10}$ Von Hagen and co-authors observe that initial conditions (in terms of output gap) were less favourable for "successful" consolidations than for "unsuccessful" ones. However, they also find that a) positive large output gaps increases the likelihood of starting fiscal consolidations, although they reduce the chances of success, and b) that fiscal consolidation is likely to start when the domestic economy is doing well compared to other economies.
} 
exchange rates as currency devaluations increase the likelihood of success. Heylen and Everaert (2000) suggest that currency devaluations prior to consolidation episodes may be beneficial to their success, but only under the right composition of fiscal adjustment - otherwise it is counterproductive. Also a favourable international economic environment (high economic growth) has generally been assessed as sustaining fiscal consolidations (Alesina and Perotti (1995) and Heylen and Everaert (2000)). There is a lack of empirical evidence, to the best of our knowledge, on the impact of private sector balance sheets and wider financial conditions in sustaining consolidations. For some euro area members, with on-going private sector balance-sheet adjustment and financial sector restructuring, weak growth prospects and large current account deficits, the ability to change course - and not simply the government's willingness to make the adjustment - will matter. The literature suggests that consolidations are more difficult after financial crises and depend crucially on the resolution of problems in the banking sector (Baldacci, Gupta and Mulas-Granados (2010); and Barrios et al. (2010)). In identifying financial factors, we follow the IMF (2008 and 2009), which identified fifteen recessions that were associated with (i.e. followed) financial crises. In doing so they relied on the narrative analysis of Reinhart and Rogoff in a series of recent papers $(2008,2009)$ describing banking crises over the past four decades. That analysis built on work identifying banking crisis episodes from the World Bank - see Caprio, Klingebiel, Laeven and Noguera (2003).

The article proceeds as follows. Section 3 outlines a definition of consolidation episodes and presents some stylised facts. Section 4 describes the analysis method, and Section 5 presents estimates of survival functions for consolidation episodes. Section 6 elaborates on the robustness of the results. Section 7 illustrates an example of the role of push and pull factors in selected euro area countries. Finally, Section 8 concludes.

\section{A definition of consolidation episodes and some initial stylized facts}

To start the analysis we need to define a sample of consolidation episodes and their duration. The literature takes two approaches. One angle is to measure fiscal consolidations based on reductions of the general government debt-to-GDP ratios accomplished during the consolidation period. In those studies, the duration of a consolidation episode is set by the period of time required to reduce debt by a given amount. The second approach, which we take here, is to assess consolidation periods according to changes in the government deficit, with most papers choosing to look at developments in the cyclically-adjusted primary budget balance (CAPB) which excludes the influence of interest rate developments and the cyclical fluctuations in economic activity on the government deficit. The duration of a consolidation period depends broadly on the length of period in which the government deficit (measured by CAPB) improves. While the use of the CAPB indicator is fairly common in the literature, it is subject to some criticism regarding its limitations to capture the macroeconomic effects of fiscal consolidations (Devries et al., 2011).

While a number of studies use the CAPB approach to defining consolidations, each study tends to set different thresholds for what constitutes the start of a consolidation and what represents an ongoing improvement. Perhaps the simplest definition, used by Maroto Illera and Mulas-Granados (2008) and von Hagen et al. (2002), is for the duration of the consolidation episode to represent the number of years in which the CAPB improves. One criticism of that approach, however, is that it captures a lot of short, small changes in the government fiscal stance, which 
might not be seen as periods of active consolidation. ${ }^{11}$ Thus others (e.g. Guichard et al. (2007)) use a stricter definition of the beginning of a consolidation period, requiring a substantial initial consolidation effort (e.g. around $1 \%$ or $1.5 \%$ over two years). Other authors define larger changes in CAPB to qualify for fiscal consolidation episode (e.g. two percentage points of GDP in one year by Alesina and Ardagna (1998)) or more refined definitions of changes in the CAPB (e.g. Afonso (2010) uses changes in CAPB at least 1.5 times the panel's standard deviation in one year, or when the change in the CAPB is at least one standard deviation on average in the last two years).

We broadly follow the OECD approach (Guichard et al., 2007) by defining a consolidation period as: starting if the CAPB improves by at least one percentage point of GDP in one year or at least one half percentage point in two consecutive years; and continuing as long as the CAPB improves (although an interruption is allowed without terminating the episode as long as the deterioration of the CAPB is small - less than $0.3 \%$ of GDP - and is more than offset the following year). However, we add two features to this definition. First, we rule out any consolidation episodes that lasted only one year - we aim to assess the factors affecting periods of sustained improvements in the CAPB and are not interested in short-lived consolidation efforts. Second, we judge that a small decline in an already better fiscal position should not represent an interruption, as a sizeable primary surplus is likely to help a country reduce its government debt. Thus for instances during a consolidation period in which countries have reached a sizeable positive CAPB defined here as $3 \%$ of GDP - we ignore any deteriorations in the CAPB that did not move the deficit below that threshold. Inevitably, the initial decision on what constitutes a consolidation episode sets the basis for the subsequent analysis. Section 5, therefore, analyses the implications of changing our definition of consolidation episodes.

Before proceeding, however, it is worth noting that changes in the CAPB are just one way of viewing a consolidation effort. In particular, the fiscal literature tends to distinguish between consolidations that are based on structural, permanent measures and those that arise from reliance on temporary or special factors. The importance of those effects is discussed by Joumard, Minegishi, André, Nicq and Price (2008) with a comprehensive overview on the nature and amount of one-off operations and their role in undermining the accuracy of CAPBs.

\footnotetext{
${ }^{11}$ Based on that definition, von Hagen et al. (2002), for example, find 122 consolidation episodes from a sample of OECD countries between 1960 and 1998. Illera and Mulas-Granados (2007) find 277 episodes of consolidation for EU countries between 1960 and 2004.
} 
Figure 1: The duration of fiscal consolidations (number of consolidations lasting for $x$ years)

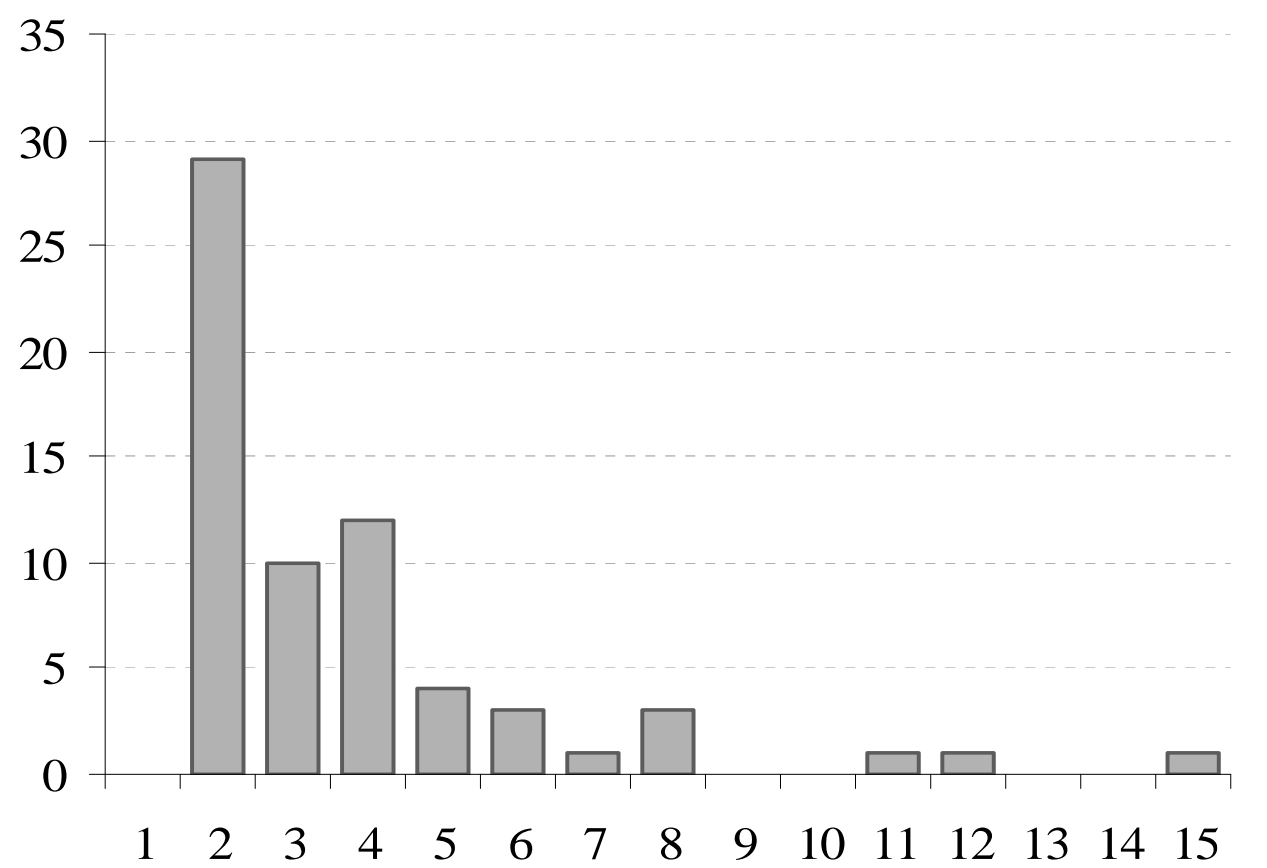

Source: OECD and author calculations.

Our study is based on an annual dataset covering 20 advanced economies over the period from 1970 to 2010, namely 14 EU countries (Austria, Belgium, Denmark, Finland, France, Germany, Greece, Ireland, Italy, the Netherlands, Portugal, Spain, Sweden, the U.K.), and 6 non-EU countries (Australia, Canada, Japan, New Zealand, Switzerland, and the U.S.). Based on our criteria and using this panel we find 65 complete episodes of consolidation as shown in Table 2. Past experience suggests consolidations have been short: nearly half of the episodes in the sample last only two years and most are over after four years. Only a few well-known cases lasted much longer: Denmark (1983-1991), Belgium (1993-2005), Ireland (1986-2001) and Japan (1979-1990). ${ }^{12}$ Overall, the average duration of fiscal adjustment in our study is just under four years, which contrasts with the findings of other approaches (for instance, two years by Giavazzi and Pagano (1996)).

\footnotetext{
12 The dates for these countries are the result of using the definition described above. Alternative definitions, of course, would yield somewhat different dates for the consolidation episodes.
} 
Table 2: Dates of consolidation episodes

\begin{tabular}{|c|c|c|c|c|c|}
\hline Country & Start & End & Country & Start & End \\
\hline Australia & 1979 & 1981 & Ireland & 1986 & 2001 \\
\hline Australia & 1986 & 1989 & Ireland & 2003 & 2007 \\
\hline Australia & 1995 & 1999 & Italy & 1976 & 1978 \\
\hline Australia & 2002 & 2004 & Italy & 1982 & 1984 \\
\hline Austria & 1996 & 1998 & Italy & 1990 & 1994 \\
\hline Belgium & 1974 & 1976 & Italy & 1995 & 2001 \\
\hline Belgium & 1984 & 1988 & Japan & 1979 & 1990 \\
\hline Belgium & 1993 & 2005 & Netherlands & 1972 & 1974 \\
\hline Belgium & 2006 & 2008 & Netherlands & 1976 & 1978 \\
\hline Canada & 1986 & 1990 & Netherlands & 1982 & 1986 \\
\hline Canada & 1994 & 2002 & Netherlands & 2004 & 2006 \\
\hline Denmark & 1983 & 1991 & New Zealand & 1991 & 1996 \\
\hline Denmark & 1999 & 2001 & New Zealand & 2002 & 2004 \\
\hline Denmark & 2004 & 2008 & Portugal & 1982 & 1985 \\
\hline Finland & 1981 & 1983 & Portugal & 2002 & 2004 \\
\hline Finland & 1984 & 1987 & Portugal & 2006 & 2008 \\
\hline Finland & 1988 & 1990 & Spain & 1986 & 1988 \\
\hline Finland & 1996 & 2004 & Spain & 1994 & 1998 \\
\hline France & 1979 & 1981 & Spain & 2005 & 2007 \\
\hline France & 1983 & 1985 & Sweden & 1975 & 1977 \\
\hline France & 1994 & 2000 & Sweden & 1983 & 1985 \\
\hline Germany & 1976 & 1978 & Sweden & 1986 & 1989 \\
\hline Germany & 1981 & 1986 & Sweden & 1994 & 1999 \\
\hline Germany & 1992 & 1995 & Sweden & 2004 & 2006 \\
\hline Germany & 1996 & 2000 & Switzerland & 1994 & 1997 \\
\hline Germany & 2005 & 2008 & Switzerland & 2005 & 2009 \\
\hline Greece & 1979 & 1981 & United Kingdom & 1979 & 1983 \\
\hline Greece & 1982 & 1984 & United Kingdom & 1994 & 2001 \\
\hline Greece & 1986 & 1988 & United States & 1976 & 1980 \\
\hline Greece & 1990 & 1995 & United States & 1987 & 1990 \\
\hline Greece & 1998 & 2001 & United States & 1993 & 1999 \\
\hline Greece & 2005 & 2007 & United States & 2005 & 2007 \\
\hline Ireland & 1982 & 1985 & & & \\
\hline
\end{tabular}

Note: OECD Economic Outlook database, variable code NLGXQA. Note that there are a further 10 episodes that begin in $\mathbf{2 0 1 0}$ which have not been concluded and are excluded from our analysis.

\section{Duration analyses}

In the subsequent analysis, we study the factors that appear to have affected the length of expansions in our sample of advanced economies, using estimates of hazard functions (e.g. Maroto Illera and Mulas-Granados, 2008). Duration analysis provides estimates of the probabilities of a consolidation coming to an end after a certain length of time. We estimate hazard functions for the duration of consolidations in the sample of advanced economies, where the duration represents the number of years of uninterrupted fiscal consolidation (according to the definition above). The hazard function measures the conditional rate at which a consolidation will come to an end. Relative to other models such as those that focus on the probability of an event taking place (e.g. a probit or logit model), the focus of duration analysis is somewhat different. The central concept in duration analysis is not the unconditional probability of an event but its conditional probability (e.g. the probability of a consolidation ending in a given year given that the expansion has lasted up to that point).

We define the length of a consolidation $(T)$, measuring the number of years from the start to the end, as a random variable with a cumulative distribution function $F(t)$ and probability density function $f(t)$. The survivor function is $S(t)=1-F(t)$, which gives the probability that the duration of a consolidation is greater than or equal to $t$. The hazard function $h(t)=f(t) / S(t)$ measures the rate at which consolidation spells will be completed at duration $t-i$.e. the probability of a budget surplus or deficit deteriorating at time $t$, conditional on the consolidation having lasted until that moment.

Broadly speaking, there are two main approaches in the literature to estimating the hazard function. One is to use a non-parametric or semi-parametric approach, most commonly associated with the Cox proportional hazards model. Although the nonparametric approach is more flexible, it can lead to less precise estimates of the hazard function than a correctly specified parametric form. The other approach, and the one taken here, is to specify and estimate a functional form for the hazard 
function. Various forms are possible, but a common approach - and the one used here - is the Weibull model:

$$
\mathrm{h}(\mathrm{t}, \mathrm{X})=\alpha \mathrm{t}^{\alpha-1} \exp \left(\beta^{\prime} X\right)
$$

where $\exp ($.$) is the exponential function and X$ is a vector of covariates which influence the hazard rate. The hazard rate (the conditional rate at which consolidations end) either rises with time $(\alpha>1)$ - which is termed "positive duration dependence", falls with time $(\alpha<1)$ or is constant. This suggests that the conditional probability of a consolidation ending increases as time passes, either as 'consolidation fatigue' sets in, or perhaps because as a consolidation continues, policymakers conclude that the 'job is done' - governments have pushed through sufficient consolidation to put finances on a sustainable path.

In the following sections we present parametric estimates, with hazard functions using the Weibull model. To check the robustness of the results, we also considered other functional forms and the non-parametric approach of the Cox proportional hazards model. In order to discriminate between models, the literature suggests a graphical analysis of the so-called Cox-Snell residuals (e.g. Arjas, 1988). That analysis suggested that, indeed, the Weibull model presents a relatively good fit for our estimated model. Another key issue is how to handle the possible presence of country level heterogeneity. Various approaches exist. One is to assume that countries have differing propensities for sustaining consolidations. These propensities - or frailties - are analogous to random effects in panel data models. An alternative is to include fixed effects or country dummies in the set of covariates. As an initial step in our estimations, we tested for the significance of fixed and random effects. However, in both instances we found the effects to be insignificant.

\section{Parametric analyses: factors sustaining the length of fiscal consolidations}

Tables 4 to 7 present estimations of hazard models for the duration of consolidation periods for our panel of advanced economies, using the Weibull model. The variables included in the models are described in Table 3. The coefficients are reported as hazard ratios - a coefficient greater than zero indicates that an increase in the explanatory variable increases the hazard rate (the conditional probability of a consolidation coming to an end). We also report a measure of explained variation, an adjusted R-squared employed for survival models (Royston (2006)). 
Table 3: Definitions of variables used in duration analyses

\begin{tabular}{|c|c|}
\hline Variable & Definition \\
\hline CAPB & Government cyclically adjusted primary balance (OECD definition) \\
\hline Government debt & Gross government debt as percent GDP \\
\hline Government debt $>90 \%$ & $\begin{array}{l}\text { Dummy variable indicating government debt-to-GDP ratio grater } \\
\text { than } 90 \%\end{array}$ \\
\hline Govt. interest payments (\% GDP) & $\begin{array}{c}\text { Gross government interest payments as percent GDP (expressed } \\
\text { as negative number) }\end{array}$ \\
\hline Real long-term interest rates & $\begin{array}{c}\text { Yields on } 10 \text { year government bonds deflated by current CPI year- } \\
\text { on-year growth }\end{array}$ \\
\hline Real short-term interest rates & $\begin{array}{c}\text { Yields on short-term government bonds deflated by current CPI } \\
\text { year-on-year growth }\end{array}$ \\
\hline Real GDP growth rate & Annual GDP growth in three years prior to consolidation \\
\hline Real potential output growth rate & Potential output growth (OECD estimate) \\
\hline Output gap & Output as percent of potential (OECD estimate) \\
\hline World GDP growth & Annual growth in World GDP (IMF) \\
\hline Current account balance & Current account balance as percent of GDP \\
\hline Private sector net lending & Private sector surplus / deficit as percent of GDP \\
\hline Private sector credit-to-GDP & Private sector credit to GDP ratio (source: BIS) \\
\hline Private sector credit growth & $\begin{array}{c}\text { Change in private sector credit-to-GDP ratio in three years prior to } \\
\text { consolidation }\end{array}$ \\
\hline Real equity price growth & $\begin{array}{c}\text { Annual growth in equity prices (deflated by } \mathrm{CPI} \text { ) in three years } \\
\text { prior to consolidation }\end{array}$ \\
\hline Financial crisis & $\begin{array}{l}\text { Dummy for occurrence of financial crisis in three years prior to } \\
\text { consolidation (source Reinhart and Rogoff }(2008) \text { ). }\end{array}$ \\
\hline Real effective exchange rate & Real effective exchange rate deflated by $\mathrm{CPI}$ \\
\hline Inflation & Annual CPI inflation in three years prior to consolidation \\
\hline $\begin{array}{l}\text { Share of consolidation - } \\
\quad \text { expenditure }\end{array}$ & $\begin{array}{l}\text { Expenditure adjustment: share of deficit change during } \\
\text { consolidation episode }\end{array}$ \\
\hline Share of consolidation - revenue & $\begin{array}{c}\text { Revenue adjustment: share of deficit change during consolidation } \\
\text { episode }\end{array}$ \\
\hline $\begin{array}{l}\text { Share of consolidation - } \\
\text { temporary measures }\end{array}$ & $\begin{array}{c}\text { Share of deficit change during consolidation episode accounted for } \\
\text { by one-off measures (OECD definition) }\end{array}$ \\
\hline Intensity of consolidation & $\begin{array}{l}\text { Average change in government deficit during consolidation } \\
\text { episode (above minimum set by consolidation definition) }\end{array}$ \\
\hline $\begin{array}{l}\text { Frontloading (consolidation in first } \\
\text { two years) }\end{array}$ & Deficit change in first two years of consolidation \\
\hline $\begin{array}{l}\text { Change in government debt over } \\
\text { consolidation }\end{array}$ & Percentage point change in debt-to-GDP ratio during consolidation \\
\hline Track record of consolidation & $\begin{array}{l}\text { Number of years of consolidation in five years prior to } \\
\text { consolidation episode }\end{array}$ \\
\hline Fiscal rules & Fiscal rules strength index (source: European Commission) \\
\hline
\end{tabular}

Source: OECD databases (unless otherwise stated).

Table 4 investigates the role of initial fiscal and financial conditions. We start by estimating the model without any covariates (column 1) and the results suggest positive duration dependence: the estimates of alpha are greater than one. Indeed, throughout the various specifications that remains the case. That means that in general, in our sample, consolidations are more likely to end as they become older. The next set of variables analyse the initial conditions before fiscal consolidations got underway. As far as possible, we would like to isolate factors driving the duration of consolidations. We therefore focus the analysis on variables in the year before the consolidation began, rather than the first year of consolidation when the impact of changes to the fiscal deficit will already be apparent. This should help ensure that the variables are exogenous - drivers of the consolidation length rather than reflections of ongoing consolidation - although we cannot control for possible expectation effects that might have arisen from the anticipation of planned consolidation efforts.

We find a strong role for the government's starting position: a larger deficit tends to presage a longer consolidation (column 2). High government debt also matters but 
is no longer statistically significant when instead we also include the government interest burden (column 3). Interestingly, we found no role for non-linearities: for example, we found no statistical evidence that government debt above a $90 \%$ (a threshold identified Reinhart and Rogoff (2012)) affected the length of consolidations. Nonetheless, market pressures would appear to play a role: higher long-term real bond yields also push governments to sustain consolidations for longer (columns 6 and 7).

Table 4: Determinants of duration of consolidations - the role of initial conditions (estimates of hazard function using Weibull model, coefficients shown as hazard ratios)

\begin{tabular}{lccccccc}
\hline & $(1)$ & $(2)$ & $(3)$ & $(4)$ & $(5)$ & $(6)$ & $(7)$ \\
\hline Duration of the episode & $0.517^{* * *}$ & $0.676^{* * *}$ & $0.703^{* * *}$ & $0.706^{* * *}$ & $0.706^{* * *}$ & $0.765^{* * *}$ & $0.759^{* * *}$ \\
Cyclically adjusted primary balance & & $0.104^{*}$ & $0.116^{*}$ & 0.094 & 0.094 & $0.108^{* *}$ & $0.110^{*}$ \\
Government debt & & $-0.021^{* * *}$ & -0.003 & -0.002 & -0.002 & & \\
Government interest burden & & & $0.197^{* * *}$ & $0.200^{* *}$ & $0.201^{* * *}$ & $0.126^{* * *}$ & $0.122^{* * *}$ \\
High government debt $(>90 \%)$ & & & & 0.151 & 0.150 & & \\
Government debt (60\% to 90\%) & & & & & -0.004 & & \\
Real long-term interest rates & & & & & & $-0.181^{* * *}$ & $-0.163^{* * *}$ \\
Real short-term interest rates & & & & & & & -0.020 \\
Constant & $-2.441^{* * *}$ & $-1.380^{* * * *}$ & $-1.646^{* * *}$ & $-1.758^{* * *}$ & $-1.757^{* * *}$ & $-1.729^{* * *}$ & $-1.726^{* * *}$ \\
\hline Number observations & 253 & 248 & 248 & 248 & 248 & 242 & 240 \\
Number of countries & 20 & 20 & 20 & 20 & 20 & 20 & 20 \\
Number of consolidations & 65 & 63 & 63 & 63 & 63 & 61 & 60 \\
Adjusted-R-squared & & 0.149 & 0.177 & 0.172 & 0.163 & 0.265 & 0.247 \\
\hline
\end{tabular}

Notes: ${ }^{* *},{ }^{* *}$ and ${ }^{*}$ indicate significance at the $1 \% .5 \%$ and $10 \%$ level respectively. Each variable is measured in the year before the consolidation begins. The "duration of the episode" reports the value of the Weibull parameter that governs the shape of the hazard function. The coefficients are reported as hazard ratios - a coefficient greater than zero indicates that an increase in the explanatory variable increases the hazard rate (the conditional probability of a consolidation coming to an end). We also report a measure of explained variation, an adjusted R-squared employed for survival models (Royston

In Table 5 we turn to investigating the role of initial macroeconomic conditions. We retain the significant 'push' factors from Table 1 - the CAPB, government interest burden and long-term bond yields - and add other macro variables. We find that a larger initial current account surplus or higher private sector surplus tends to help sustain consolidations (columns 2 and 3), even once we have accounted for the role of the government deficit. Higher private sector saving (as a percent of GDP) also appears to reduce the probability of consolidations ending (column 4). There is more mixed evidence on the role of financial conditions. A high stock of private sector debt is not a significant explanatory factor but strong credit growth in the period before the consolidation does appear to affect the likelihood of a sustained consolidation (columns 5 and 6). Perhaps because strong credit growth may subsequently require retrenchment from the private non-financial and financial sectors, we find that higher private sector credit growth in the years prior to the consolidation tends to reduce the duration of the consolidation. A similar role for boom-bust dynamics may explain why strong growth in equity prices in the years before a consolidation episode also tends to reduce the duration (column 7). That finding might reflect the suggestion from Mian, Sufi and Trebbi (2012) that in a post-boom phase countries become highly politically polarized following financial crises, and as a result, sustained consolidation efforts are more difficult. We do not find the dummy for financial crises to be significant (column 8), which might be explained by two factors. First, the impact of the financial crisis on the duration of subsequent consolidation efforts may simply be seen most through the deleterious effect on the fiscal position which then push governments towards consolidation. 
Second, it may be that following a financial crisis, the state of private sector balance sheets (captured in other variables in our model) is a more important determinant of how effectively governments can tackle the subsequent need for retrenchment.

Table 5: Determinants of duration of consolidations - the role of macroeconomic conditions (estimates of hazard function using Weibull model, coefficients shown as hazard ratios)

\begin{tabular}{|c|c|c|c|c|c|c|c|c|}
\hline & (1) & (2) & (3) & (4) & (5) & (6) & (7) & (8) \\
\hline Duration of the episode & $0.765 * * *$ & $0.832 * * *$ & $0.831^{* * *}$ & $0.856^{* * *}$ & $0.770 * * *$ & $0.780^{* * *}$ & $0.768 * * *$ & $0.759 * * *$ \\
\hline CAPB & $0.108^{* *}$ & $0.164^{* * *}$ & $0.080^{*}$ & $0.080^{* *}$ & $0.117^{* *}$ & 0.073 & $0.096^{*}$ & $0.107^{* *}$ \\
\hline Government interest burden & $0.126 * * *$ & $0.175^{* * *}$ & 0.092 & $0.126^{* *}$ & $0.156^{* * * *}$ & $0.127 * *$ & $0.113^{* *}$ & $0.126 * * *$ \\
\hline Real long-term interest rates & $-0.181 * * *$ & $-0.178 * * *$ & $-0.177 * * *$ & $-0.222 * * *$ & $-0.173 * * *$ & $-0.168 * * *$ & $-0.230 * * *$ & $-0.187 * * *$ \\
\hline Current account balance & & $-0.081^{* * *}$ & & & & & & \\
\hline Private sector net lending & & & $-0.081^{* * *}$ & & & & & \\
\hline Private saving ratio & & & & $-0.080^{*}$ & & & & \\
\hline Credit to GDP ratio & & & & & -0.005 & & & \\
\hline Change in credit to GDP ratio & & & & & & $0.063^{*}$ & & \\
\hline Real equity price growth & & & & & & & $0.020^{*}$ & \\
\hline Financial cris is & & & & & & & & 0.324 \\
\hline Constant & $-1.729 * * *$ & $-1.742 * * *$ & $-1.827 * * *$ & -0.239 & $-1.254 * * *$ & $-1.956 * * *$ & $-1.789 * * *$ & $-1.717 * * *$ \\
\hline Number observations & 242 & 228 & 228 & 232 & 234 & 232 & 237 & 232 \\
\hline Number of countries & 20 & 19 & 19 & 20 & 19 & 19 & 20 & 20 \\
\hline Number of consolidations & 61 & 57 & 57 & 57 & 58 & 57 & 59 & 61 \\
\hline \multirow[t]{2}{*}{ Adjusted-R-squared } & 0.265 & 0.296 & 0.302 & 0.321 & 0.275 & 0.275 & 0.272 & 0.252 \\
\hline & (9) & (10) & (11) & (12) & (13) & (14) & (15) & (16) \\
\hline Duration of the episode & $0.794 * * *$ & $0.774 * * *$ & $0.761 * * *$ & $0.807 * * *$ & $0.886 * * *$ & $0.765^{* * *}$ & $0.802 * * *$ & $0.759 * * *$ \\
\hline CAPB & $0.100 * *$ & $0.091 *$ & $0.101^{*}$ & 0.065 & $0.076^{*}$ & $0.113^{* *}$ & $0.155^{* * * *}$ & $0.110^{*}$ \\
\hline Government interest burden & $0.146 * * *$ & $0.128 * * *$ & $0.125^{* *}$ & $0.104 *$ & $0.220 * * *$ & $0.125 * * *$ & $0.178 * * *$ & $0.122 * * *$ \\
\hline Real long-term interest rates & $-0.187 * * *$ & $-0.162 * * *$ & $-0.170 * * *$ & $-0.191^{* * *}$ & $-0.155^{* * *}$ & $-0.181^{* * *}$ & $-0.108^{* *}$ & $-0.163 * * *$ \\
\hline GDP growth & -0.101 & & & & & & & \\
\hline World GDP growth & & 0.363 & & & & & & \\
\hline Output gap & & & 0.061 & & & & & \\
\hline Real exchange rate & & & & $0.026^{* *}$ & & & & \\
\hline Relative ULC growth & & & & & $0.201 * * *$ & & & \\
\hline Openness & & & & & & -0.001 & & \\
\hline Inflation & & & & & & & $0.084 * * *$ & \\
\hline Monetary policy interest rate & & & & & & & & -0.020 \\
\hline Constant & $-1.488^{* * *}$ & $-3.155^{* * *}$ & $-1.713^{* * *}$ & $-4.500 * * *$ & $-1.770 * * *$ & $-1.683^{* * *}$ & $-2.253^{* * *}$ & $-1.726 * * *$ \\
\hline Number observations & 240 & 232 & 242 & 232 & 228 & 242 & 240 & 240 \\
\hline Number of countries & 20 & 20 & 20 & 20 & 19 & 20 & 20 & 20 \\
\hline Number of consolidations & 60 & 61 & 61 & 58 & 56 & 61 & 60 & 60 \\
\hline Adjusted-R-squared & 0.261 & 0.267 & 0.264 & 0.296 & 0.342 & 0.257 & 0.286 & 0.247 \\
\hline
\end{tabular}

Notes: ${ }^{* * *},{ }^{* *}$ and ${ }^{*}$ indicate significance at the $1 \% .5 \%$ and $10 \%$ level respectively. Each variable is measured in the year before the consolidation begins. The "duration of the episode" reports the value of the Weibull parameter that governs the shape of the hazard function. The coefficients are reported as

hazard ratios - a coefficient greater than zero indicates that an increase in the explanatory variable increases the hazard rate (the conditional probability of a consolidation coming to an end). The measure of explained variation is an adjusted R-squared employed for survival models (Royston (2006)).

We tested a number of other variables. The role of growth dynamics is unclear: a higher real GDP growth rate tends to increase the probability of a consolidation continuing but a larger output gap lowers the probability of a sustained consolidation. Moreover, none of the coefficients are statistically significant (columns 9 and 10). In combination with other variables we find that stronger real GDP growth at the onset of a consolidation period is typically associated with a longer-lasting consolidation effort. The international environment - proxied by world real GDP growth - played no significant role. The important role for competitiveness is confirmed: a more competitive real exchange rate and smaller 
increases in unit labour costs (relative to other advanced economies) in the lead-up to a consolidation tend to increase the likelihood that the consolidation will last (columns 12 and 13). We find no additional explanatory power from the openness of an economy, measured as the ratio of exports to GDP (column 14). Moreover, stronger inflation in the years preceding the start of consolidation tends to reduce the length of subsequent consolidations (column 15). But, the coefficient on the monetary policy interest rate is insignificant (column 16). This is line with the literature, which does not find a uniformly significant role for monetary policy in affecting the length of consolidation periods.

Table 6: Determinants of duration of consolidations - fiscal policy and the fiscal framework (estimates of hazard function using Weibull model, coefficients shown as hazard ratios)

\begin{tabular}{|c|c|c|c|c|c|c|c|c|c|c|}
\hline & (1) & (2) & (3) & (4) & (5) & (6) & (7) & (8) & (9) & (10) \\
\hline Duration of the episode & $0.765 * * *$ & $0.832 * * *$ & $0.831^{* * *}$ & $0.856^{* * *}$ & $0.770^{* * *}$ & $0.780 * * *$ & $0.768^{* * * *}$ & $0.794^{* * *}$ & $0.772^{* * *}$ & $0.761^{* * *}$ \\
\hline CAPB & 0.074 & 0.074 & 0.111 & 0.011 & 0.070 & $0.367 * * *$ & 0.126 & 0.074 & 0.068 & -0.008 \\
\hline Government interest burden & $0.242 * * *$ & $0.267 * * *$ & $0.288^{* * *}$ & $0.297^{* * *}$ & $0.246^{* * *}$ & $0.304^{* * *}$ & $0.277^{* * *}$ & $0.236^{* * *}$ & $0.234^{* * *}$ & 0.116 \\
\hline Real long-term interest rates & $-0.115^{*}$ & -0.109 & $-0.122^{*}$ & $-0.149 *$ & $-0.118^{*}$ & $-0.149 * *$ & $-0.119 *$ & $-0.128 *$ & $-0.117 *$ & $-0.683 * * *$ \\
\hline Current account balance & $-0.080^{* *}$ & $-0.084^{* *}$ & $-0.088^{* *}$ & -0.008 & $-0.079 * *$ & $-0.066 *$ & $-0.088 * *$ & $-0.081 * *$ & $-0.081^{* *}$ & -0.069 \\
\hline Change in credit to GDP ratio & $0.087^{* *}$ & $0.102^{* * *}$ & $0.095^{* *}$ & $0.102^{* *}$ & $0.086^{* *}$ & $0.093 * * *$ & 0.059 & $0.091^{* *}$ & $0.087^{* *}$ & 0.087 \\
\hline Real exchange rate & $0.037^{*}$ & $0.043^{* *}$ & $0.046^{* *}$ & 0.020 & $0.036^{*}$ & 0.028 & 0.031 & $0.035 *$ & $0.036^{*}$ & $0.122 * * *$ \\
\hline GDP growth & $-0.221^{*}$ & $-0.228 * *$ & $-0.209 *$ & -0.058 & $-0.224^{*}$ & $-0.212^{*}$ & $-0.211^{*}$ & $-0.263^{* *}$ & $-0.221^{*}$ & 0.002 \\
\hline Inflation & $0.104^{* *}$ & $0.116^{* *}$ & $0.125^{* *}$ & $0.146^{* * *}$ & $0.105^{* *}$ & $0.111^{* *}$ & $0.100 * *$ & 0.087 & $0.100^{*}$ & 0.209 \\
\hline \multicolumn{11}{|l|}{ Consolidation composition: } \\
\hline Expenditure share & & 0.001 & & & & & & & & \\
\hline Revenue share & & & -0.003 & & & & & & & \\
\hline Temporary measures share & & & & $0.012^{* *}$ & & & & & & \\
\hline Track record in consolidation & & & & & 0.032 & & & & & \\
\hline Intensity of consolidation & & & & & & $2.461 * * *$ & & & & \\
\hline Frontloading & & & & & & & 0.150 & & & \\
\hline Change in debt & & & & & & & & 0.024 & & \\
\hline Election & & & & & & & & & 0.172 & \\
\hline Fiscal rules & & & & & & & & & & $0.411^{*}$ \\
\hline Constant & $-6.055^{* * *}$ & $-6.585 * * *$ & $-6.694^{* * *}$ & $-5.234^{* *}$ & $-6.049 * * *$ & $-5.689 * * *$ & $-5.462 * *$ & $-5.634^{* *}$ & $-6.052^{* * *}$ & $-16.100^{* * *}$ \\
\hline Number observations & 210 & 200 & 200 & 173 & 210 & 200 & 210 & 195 & 210 & 96 \\
\hline Number of countries & 19 & 19 & 19 & 18 & 19 & 19 & 19 & 19 & 19 & 13 \\
\hline Number of consolidations & 51 & 51 & 51 & 44 & 51 & 51 & 51 & 49 & 51 & 22 \\
\hline Adjusted-R-squared & 0.394 & 0.393 & 0.404 & 0.472 & 0.385 & 0.476 & 0.395 & 0.384 & 0.387 & 0.627 \\
\hline
\end{tabular}

Notes: ${ }^{* *},{ }^{* *}$ and ${ }^{*}$ indicate significance at the $1 \% .5 \%$ and $10 \%$ level, respectively. Each variable is measured in the year before the consolidation begins. The "duration of the episode" reports the value of the Weibull parameter that governs the shape of the hazard function. The coefficients are reported as hazard ratios - a coefficient greater than zero indicates that an increase in the explanatory variable increases the hazard rate (the conditional probability of a consolidation coming to an end). We also report a measure of explained variation, an adjusted R-squared employed for survival models (Royston (2006)).

Having analysed the macroeconomic backdrop to consolidation episodes, we turn to the role of fiscal policy choices. Table 6 presents the estimations for duration of consolidation, again using the Weibull model. We retain the set of initial conditions that proved to be significant and add different indicators of fiscal policy, including indicators of the composition of adjustment, the temporality of the adjustment, the size and pace of consolidation and the strength of the governance framework. A key finding in the literature is that the composition of consolidation - the split between expenditure and revenue measures - is important (e.g. Maroto Illera and Mulas-Granados (2008), von Hagen et al. (2002)). In columns two and three we add variables that indicate the proportion of deficit reduction during the consolidation phase accounted for by changes in current expenditure, and current revenue. In contrast to several studies in the literature, we find the coefficients on the composition variables to be insignificant. Once we have accounted for the role 
of initial macroeconomic conditions, the composition of the fiscal adjustment - the split between revenue and expenditure measures - does not appear to be a significant determinant of the duration of consolidation. ${ }^{13}$ But the dimension that does appear to play a role is the durability of the adjustment. Our evidence suggests that consolidations lasted longer when one-off measures played a smaller role (column 4). One explanation is that the key to successful consolidation efforts is linked to the commitment of the government in approaching the task, seeking for a permanent rather than a temporary change to the fiscal position. ${ }^{14}$

The results for other features of fiscal policy choices are generally in line with the literature. We find that the intensity of deficit reduction - the average pace of improvement in the CAPB over the consolidation episode - is significant. Longerlasting consolidation episodes were based on rather gradual improvements in government deficit positions. However, we find no evidence that the amount of frontloading of the consolidation effort is a signal of greater willingness or ability to sustain consolidation efforts for longer. Neither do we find a significant role for a country's track record of consolidation. Elections do not appear to signal the end of a consolidation episode.

\section{Examining the robustness of the results}

To assess the robustness of the results we checked variations to the definition of consolidation: first, we included in the sample consolidation periods lasting only one year; second we specified a higher starting hurdle - i.e. a greater initial change in the fiscal position (of at least $1.5 \%$ in the first two years); third we allowed for more gradual deficit reductions to qualify, with a lower initial threshold (only $0.5 \%$ over the first two years). These alternative definitions yielded respectively 101, 76 and 52 consolidation episodes. In general, in neither case did we see large changes to our findings. Most variables that were significant using our main definition were also significant under these alternative specifications. In particular, we still find a strong role for the starting fiscal position: the initial deficit, interest burden and long-term real bond yields. Most macro conditions also remained significant. In particular, the external position and competitiveness remained important indicators of sustainable consolidation. Two exceptions, however, were in the roles of growth and inflation in the run up to consolidation, which were less consistently significant predictors of the duration of consolidations using these alternative definitions. Finally, we also investigate whether adjustments to our sample affected the results. One concern might be that the outliers - in particular the three long consolidations in Belgium, Ireland and Japan - have affected the results. However, rerunning the estimations excluding these observations, we found the results to be very similar.

\footnotetext{
${ }^{13}$ To check this finding, we also used a more detailed breakdown of government revenue and spending, separating the proportion of deficit reduction in each consolidation episode by types of expenditure and revenue. Following von Hagen et al. (2002) we added to each equation a variable showing the contribution of a particular budget item to the total deficit reduction achieved during the consolidation episode. All but one coefficient (that on capital expenditure) is statistically insignificant suggesting that there is overall not strong support for the view that the composition of deficit reductions is an important determinant of the length of consolidation periods. We also investigated different definitions for the fiscal composition - e.g. using a dummy variable to define whether the adjustment was predominantly expenditure- or revenue-based etc. In none of the cases were the variables statistically significant.

${ }^{14}$ However, the role of the fiscal rules could not be demonstrated, as the analysis (column 10) shows a curious result that stronger fiscal rules appear to increase the likelihood of a consolidation episode ending. Moreover, with the series for the fiscal rules strength index available only for EU countries from 1990 onwards, the sample of consolidation episodes is considerably smaller, and therefore the results are limited.
} 


\section{The role of push factors and pull factors in euro area countries}

To illustrate the insights from our work, we use our results to illustrate some of the challenges that lie ahead for some euro area countries that have embarked on a consolidation path during 2010-11. While, for several Member States the push factors are obvious, with high public debt levels, large deficits, high sovereign bond yields and rising interest burdens forcing governments to take strong action towards fiscal austerity, there are clear challenges too. This is particularly true for those countries suffering from twin deficits of large fiscal and current account imbalances and cumulated competitiveness problems. In this sense, Figure 2 shows survivor curves for the duration of the current fiscal consolidation efforts in countries under EU/IMF economic and financial programmes (Ireland, Greece and Portugal) as well as Spain and Italy. Figure 3 shows a decomposition of the factors affecting the estimated probability of a duration lasting at least five years. The probability estimates are based on the equation which includes the initial fiscal conditions - deficit, bond yields and interest payments - and macroeconomic capacity - current account, real effective exchange rate, recent credit developments and growth and inflation dynamics. To provide a common overview, the estimated starting point is 2010 . The estimated probabilities that these countries will be able to maintain a sustained consolidation effort are generally quite low. That should not be a surprise: the estimates are derived from analysis of past experiences and previous examples of long-lasting consolidation are relatively rare, as Figure 1 highlighted. For example, from our sample, the unconditional probability of consolidation lasting longer than five years is under a half.

Figure 2: Estimated survivor curves for current fiscal consolidation efforts in selected euro area countries (probability of consolidation lasting to particular year)

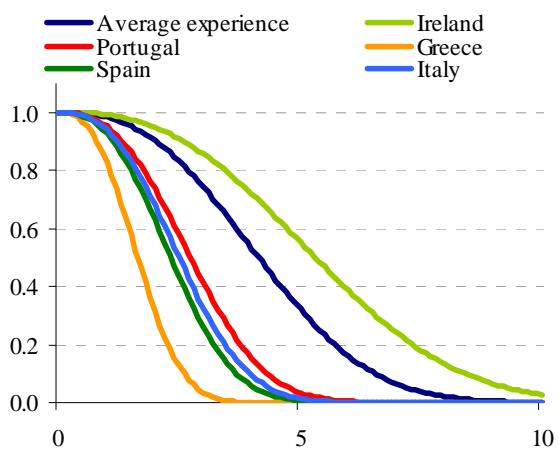

Notes: survivor functions estimated using Weibull distribution assumption for baseline hazard (see Table 6, column 1). The "average experience" shows the average estimated probability assuming all explanatory variables are at their mean. Other curves show estimates of the probabilities for Ireland, Greece and Portugal based on current developments.
Figure 3: Factors affecting current probabilities of achieving long-lasting consolidation in selected euro area countries (contribution to estimated probability of consolidations starting in 2010 lasting five years or more)

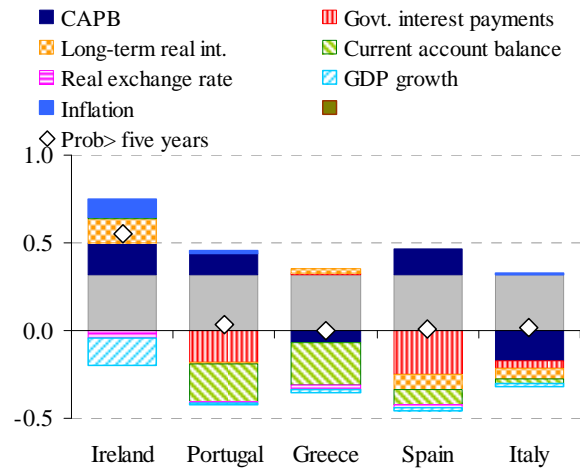

Notes: survivor functions estimated using Weibull distribution assumption for baseline hazard (see Table 6, column 1). The "average experience" shows the average estimated probability assuming all explanatory variables are at their mean. The other contributions show the effect of each variable relative to the mean experience.

However, there are interesting differences in the estimated probabilities for each country which highlight the potential varied pressures in each situation. For instance, according to the estimates, Ireland appears considerably more likely to maintain fiscal consolidation than the other countries from the sample. Some of the drivers for Ireland are the 'push' factors that make consolidation a necessity, such 
as the high primary deficit, relatively heavy interest burden and high long-term real bond yields. Yet the recent improvement in Ireland's competitive position, with relatively low inflation and unit labour cost growth, as well as the return towards current account balance, could also be expected to help Ireland's consolidation effort. These rebalancing efforts in the Irish economy are further supported by the return to the capital markets during 2012.

By contrast, Greece suffers from continued poor competitiveness (a high real exchange rate and continued high unit labour cost growth) which, combined with a large current account surplus, underscores the apparent difficulty for the government to achieve lasting fiscal consolidation. The relatively low likelihood shown for Greece in Figure 2 was confirmed by the need to restructure its government debt in Spring 2012. Portugal's problems are also related to lack of competitiveness and continued high current account deficit. Another finding is that countries with less dominant 'push' factors (lower interest payments like Spain or stronger CAPB position like Italy) show also a relatively lower probability of sustaining long consolidations.

As discussed above, one needs to recall that this analysis uses as the starting point the situation in $2010 .^{15}$ Developments during 2011 would perhaps have heightened concerns that these countries also needed to implement consolidation in the coming years. Moreover, the estimates omit some important elements to the current efforts, such as the role of the institutional framework of the EU/IMF programmes in sustaining consolidations. ${ }^{16}$

\section{Conclusions}

This article has presented analysis of the factors affecting the duration of past consolidations in advanced economies. Our analysis suggests that the starting point matters - the fiscal and macroeconomic conditions appear to influence the success of governments in sustaining lengthy consolidations. In line with the literature, we find that governments often appear to have been 'pushed' towards sustained fiscal consolidations - the duration of consolidation is driven by the need to adjust course: longer consolidations occur when public debt is high, fiscal deficits are large, the interest burden heavy and long-term bond yields elevated. Our contribution to the literature is to put considerably more emphasis on the macroeconomic backdrop to consolidation episodes. We find that other factors, what we call pull factors, affect the duration of consolidations: a countries' capacity to change course or its room for manoeuvre is important. Higher initial private sector savings and a stronger external balance appear to help governments sustain longer-lasting consolidations. The important role for competitiveness is underlined: a more competitive real exchange rate in the lead-up to a consolidation tends to increase the likelihood of a sustained fiscal adjustment. Finally, in contrast to some studies in the literature, we also find that there is less prominence for factors that might indicate a government's willingness or resolve in its approach to consolidation. In particular, once we have accounted for the role macroeconomic conditions, the composition of the fiscal adjustment - the split between expenditure and revenue measures - does not appear to be a significant determinant of the duration of consolidation. However, commitment to permanent, rather than temporary, fiscal adjustment is key.

\footnotetext{
${ }^{15}$ The regression estimates use the situation in the year before consolidation began. In this framework, for an assessment of the consolidation prospects from 2011 onwards, it is therefore the situation in 2010 that affects the length of consolidation.

${ }^{16}$ See, for example, Gupta et al. (2004) who analyse a wide dataset for countries with IMF-supported programmes in the 1990s.
} 


\section{References}

Afonso, António (2010) 'Expansionary Fiscal Consolidations in Europe: New Evidence', Applied Economics Letters 17(2): 105-109.

Agnello, Luca, Vitor Castro and Ricardo Sousa (2012) 'What determines the duration of a fiscal consolidation program?', NIPE Working Paper No 17.

Ahrend, Rudiger, Pietro Catte and Robert Price (2006) 'Interactions between Monetary and Fiscal Policy: How Monetary Conditions Affect Fiscal Consolidation', OECD Working Paper, No 521.

Alesina, Alberto and Silvia Ardagna (1998) 'Tales of Fiscal Adjustment', Economic Policy 13(27): 487-545.

Alesina, Alberto and Roberto Perotti (1995) 'Fiscal Expansions and Fiscal Adjustments in OECD Countries', Economic Policy 21(2): 205-248.

Alesina, Alberto and Roberto Perotti (1997) 'Fiscal Adjustments in OECD Countries: Composition and Macroeconomic Effects', IMF Staff Papers 44(2):210248.

Alesina, Alberto, Roberto Perotti and José Tavares (1998) 'The Political Economy of Fiscal Adjustments', Brookings Papers on Economic Activity 29(1): 197-266.

Ardagna, Silvia (2004) 'Fiscal Stabilisations: When do they Work and Why', European Economic Review 48(5): 1047-1074.

Arjas, E. (1988) 'A graphical method for assessing goodness of fit in Cox's proportional hazards model', Journal of the American Statistical Association 83(401): 204-212.

Baldacci, Emanuele, Sanjeev Gupta and Carlos Mulas-Granados (2010) 'Restoring Debt Sustainability After Crises: Implications for the Fiscal Mix', IMF Working Paper No 232.

Barrios Salvador, Sven Langedijk and Lucio Pench (2010) 'EU fiscal Consolidation After the Financial Crisis: Lessons from Past Experiences', European Commission Economic Papers No 418.

Bracke, Philippe (2011) 'How Long Do Housing Cycles Last? A Duration Analysis for 19 OECD Countries', IMF Working Paper No 231.

Briotti, Maria Gabriella (2004) 'Fiscal Adjustment between 1991 and 2002: Stylised Facts and Policy Implications', ECB Occasional Paper Series, No 9.

Buchanan, James M. and Gordon Tullock (1962) The Calculus of Consent: Logical Foundations of Constitutional Democracy, Ann Arbor, Ml: University of Michigan Press.

Buchanan, James M. and Richard E. Wagner (1977) Democracy in Deficit: The Political Legacy of Lord Keynes. New York: Academic Press.

Caprio, Gerard, Daniela Klingebiel, Luc Laeven and Guillermo Noguera (2003) 'Banking crisis database: An update of the Caprio-Klingebiel Database (1996, 1999), October 2003', URL (consulted June 2013): www1.worldbank.org/finance/html/database_sfd.html.

Devries, Pete, Jaime Guajardo, Daniel Leigh and Andrea Pescatori (2011) 'A New Action-based Dataset of Fiscal Consolidation', IMF Working Paper No. 128.

European Central Bank (2011) 'Past Experience with Sustaining Large Primary Budget Surpluses', Monthly Bulletin, April, 94-95.

European Commission (2007) 'Public Finances in EMU - 2007', European Economy 3/2007, Directorate-General for Economic and Financial Affairs. 
European Commission (2011) 'Public Finances in EMU - 2011', European Economy 3/2011, Directorate-General for Economic and Financial Affairs.

Giavazzi, Francesco and Marco Pagano (1996) 'Non-keynesian Effects of Fiscal Policies Changes: International Evidence and the Swedish evidence', Swedish Economic Policy Review 3(1): 67-112.

Guichard, Stéphanie, Mike Kennedy, Eckhard Wurzel and Christophe André (2007) 'What Promotes Fiscal Consolidation: OECD Country Experience', OECD Working Papers No 553.

Gupta, Sanjeev, Benedict Clements, Emanuele Baldacci and Carlos MulasGranados (2004) 'The Persistence of Fiscal Adjustments in Developing Countries', Applied Economic Letters 11(4): 209-212.

Hartwig Lojsch, Dagmar, Marta Rodríguez-Vives and Michal Slavik (2011) 'The Size and Composition of Government Debt in the Euro Area', ECB Occasional Paper Series No. 132.

Heylen, Freddy and Gerdie Everaert (2000) 'Success and Failure of Fiscal Consolidation in the OECD: A Multivariate Analysis', Public Choice 105(1-2): 103124.

Hernández de Cos, Pablo and Enrique Moral-Benito (2011) 'Endogenous Fiscal Consolidations', Documentos de Trabajo del Banco de Espana No. 1102.

International Monetary Fund (2008) 'What Happens during Recessions, Crunches and Busts?', IMF Working Paper No 274.

International Monetary Fund (2009) World Economic Outlook April 2009: Crisis and Recovery. Washington, DC: International Monetary Fund.

Joumard, Isabelle, Makoto Minegishi, Christophe André, Chantal Nicqand and Robert Price (2008) 'Accounting for one-off operations when assessing underlying fiscal positions', OECD Working Paper No 50.

Kiefer, Nicholas M. (1988) 'Economic Duration Data and Hazard Functions', Journal of Economic Literature 26(2): 646-679.

Larch, Martin and Alessandro Turrini (2008) 'Received Wisdom and Beyond: Lessons from Fiscal Consolidation in the EU', European Commission, Economic Papers No 320.

Maroto Illera, R. and C. Mulas-Granados (2008) 'What makes fiscal consolidations last? A survival analysis of budget cuts in Europe (1960-2004)', Public Choice 134(3): 147-161.

Mian, Atif R., Amir Sufi and Francesco Trebbi (2012) 'Resolving Debt Overhang: Political Constraints in the Aftermath of Financial Crises', NBER Working Paper No 17831.

Molnár, Margit (2012) 'Fiscal consolidation: What factors determine the success of consolidation efforts?', OECD Economics Department Working Papers No 936.

Reinhart, Carmen and Kennet Rogoff (2008a) 'Is the 2007 US Sub-prime Crisis so Different?', NBER Working Paper No 13761.

Reinhart, Carmen and Kennet Rogoff (2008b) 'Banking Crises: An Equal Opportunity Menace', NBER Working Paper No 14587.

Reinhart, Carmen and Kennet Rogoff (2009) 'The Aftermath of Financial Crises', American Economic Review 99(2): 466-472.

Reinhart, Carmen and Kennet Rogoff (2012) 'Debt Overhangs: Past and Present', NBER Working Paper No 18015. 
Royston, Patrick (2006) 'Explained variation for survival models', The Stata Journal 6(1): 83-96.

von Hagen, Jürgen, Andrew Hughes Hallett and Rolf Strauch (2002) 'Budgetary Consolidation in Europe: Quality, Economic conditions, and Persistence', Journal of the Japanese and International Economies 16(4):512-535.

von Hagen, Jürgen and Rolf Strauch (2001) 'Fiscal consolidation: Quality, Economic Conditions and Success', Public Choice 109(3-4): 327-346. 